Vargas, F. B., Bataglin, F. S., and Formoso, C. T., (2018). "Guidelines to develop a BIM model focused on construction planning and control." In: Proc. $26^{\text {th }}$ Annual Conference of the International. Group for Lean Construction (IGLC), González, V.A. (ed.), Chennai, India, pp. 744-753. DOI: doi.org/10.24928/2018/0450. Available at: www.iglc.net.

\title{
GUIDELINES TO DEVELOP A BIM MODEL FOCUSED ON CONSTRUCTION PLANNING AND CONTROL
}

\author{
Fabrício Berger de Vargas', Fernanda Saidelles Bataglin², \\ and Carlos Torres Formoso ${ }^{3}$
}

\begin{abstract}
Information pulled from 4D simulations may be used to compare construction scenarios as well as to support decision-making in production planning and control. Different projects, software, tools and planning methods result in a diversity of inputs that should be considered while trying to fulfil 4D simulation needs. If those are not properly addressed, it may lead to inconsistencies and lack of suitable information. The existing literature on 4D BIM does not provide much advice on which information should be considered to develop a 4D simulation. The aim of this paper is to propose a set of guidelines to devise BIM models to support production planning and control with emphasis on Lean Construction principles and concepts. Design Science Research was the methodological approach adopted in this investigation, which was based on three empirical studies. The main contributions of this study are concerning with understanding the sources of information for3D modelling and how information should be gathered so that 4D BIM model scan effectively support planning and control decisions. A model based on these guidelines should provide relevant information to support decision making, and consequently contribute to reduce variability, increase data reliability, eliminate nonvalue adding activities and reduce $3 \mathrm{D}$ modelling time.
\end{abstract}

\section{KEYWORDS}

Modelling inputs, 4D simulation, production planning and control, lean principles.

\section{INTRODUCTION}

Construction planning is the production of cost estimates, schedules, and other detailed specifications of the steps to be followed and the constraints to be managed in project execution (Ballard and Howell 1998). Once production begins, managers should make efforts to control, i.e., monitoring performance against those specifications, to perform

\footnotetext{
1 M.Sc. Student, Building Innovation Research Unit (NORIE), Federal University of Rio Grande do Sul (UFRGS), Porto Alegre, Brazil, fabriciovargas@live.com

$2 \quad$ Ph.D Candidate, NORIE, UFRGS, Porto Alegre, Brazil, fernanda.saidelles@ gmail.com

3 Professor, School of EngineeringNORIE, UFRGS, Porto Alegre, Brazil, formoso@ufrgs.br
} 
corrective actions whenever needed to achieve a desired performance(Ballard and Howell 1998). The effectiveness of production planning and control in construction depends significantly on the reliability and timeliness of resource information (equipment, labour and materials) (Dave et al. 2011).Any improvement in information quality, which is used as inputs for planning processes, should therefore positively affect planning quality, planning outputs and possibly improve predictability of project delivery(Gledson and Greenwood 2017).

According to Crotty (2012), Building Information Modelling (BIM) can be usedto improve the quality of building design information and to establish mechanisms and procedures by which information is communicated and shared amongproject team members. Fundamentally, a project team cannot produce great results without trustworthy information and reliable workflows (Fosse et al. 2017). Sacks et al. (2010)pointed out that there are several interactions between Lean principles and BIM functionalities that support the argument that several synergies exist between them. This implies that to enhance lean outcomes, the adoption of BIM should be considered (Sacks et al. 2010).

4D simulations consist in assigning tasks from project schedules to 3D BIM elements in order to visualize the construction process over time (Boton et al. 2015). These enhancements should enable planners to produce more reliable schedules and communicate planning decisions more effectively (e.g. construction sequencing). This effective communication enables directing the plan recipient toward the exact location of work content and even visualize impacts of resource movement and site logistics(Gledson and Greenwood 2014).According to Eastman et al. (2011), even though planning and scheduling processes may vary depending on the tools adopted, there are several issues that any planner or 4D modelling team should consider while preparing and developing a 4D model.

Research efforts have pointed out advantages of BIM, especially by using 4D simulation to support production planning and control, such as analysing the use of construction site space (Heesom and Mahdjoubi 2002), planning resource utilization (Li et al. 2009), planning for safety (Sulankivi et al. 2010), improving construction site layout (Zhang and Li 2010), analysing and monitoring construction progress (Kim et al. 2013), and planning workflows(Li et al. 2014).Those studies have focused on practical applications of 4D existing tools or in the development of new solutions, integrating the 4D environment to other software tools. However, only a few of those studies have explained clearly which information should be considered to build up a BIM model for 4D simulations. Moreover, most of them have not emphasised the efforts required and possible problems that modellers may face. Based on that, the aim of this paper is to propose a set of guidelines to devise BIM models to support production planning and control with emphasis on Lean Construction principles and concepts. These guidelines are based on three empirical studies carried out in different construction sites.

\section{RESEARCH METHOD}

Design Science Research (DSR) was the methodological approach adopted in this study. The goal of DSR involves the development of an innovative artefact to solve a practical 
problem at the same time it produces scientific knowledge (Holmström et al. 2009), and making also a theoretical contribution (Kasanen et al. 1993). Even though this research adopted DSR, the empirical studies were carried out as Action Research (AR) studies: representatives of the companies were fully engaged in the implementation of changes, and there were several learning cycles during the research process.

For each empirical study the research process was divided into the following phases: understanding the problem, development of the artefact, and analysis and reflection. The first phase consisted in understanding companies' context and production planning and control methods adopted. In Empirical Studies 1 and 3, as there was no BIM model available at the beginning, the research team defined the purposes, strategies and criteria to develop BIM models. In Empirical Study2, the model was made available by the architectural design firm. In the development phase, the 4D BIM model was built to support production planning and control. The development of the 4D BIM model was based on stakeholders needs and intended use. Finally, the analysis and reflection of the results were made and as a result of this phase, a set of guidelines was proposed.

Data from three empirical studies were retrospectively analysed and are the background and source of information for the guidelines established. Some key information regarding these empirical studies are compiled in Figure, indicating the software used, whether the model was developed or provided by the company, companies' description, brief description of the projects, as well as the sources of evidence used.

\begin{tabular}{|c|c|c|c|}
\hline & \multicolumn{2}{|c|}{ Research A } & \multirow{2}{*}{$\begin{array}{l}\text { Research B } \\
\text { CASE } 3 \text { (11 months) }\end{array}$} \\
\hline & CASE 1 (12 months) & CASE 2 (5 months) & \\
\hline Softv & $\begin{array}{c}\text { 3D model - ArchiCAD } 20 \\
\text { 4D simulation - Vico Office R6.1 }\end{array}$ & $\begin{array}{c}\text { 3D model - Revit } 2018 \\
\text { 4D simulation - Vico Office R6.5 }\end{array}$ & $\begin{array}{l}\text { 3D model - Revit } 2017 \\
\text { 4D simulation - Synchro Pro }\end{array}$ \\
\hline $\begin{array}{l}\text { 3D } \\
\text { model }\end{array}$ & $\begin{array}{l}\text { Researchers developed the 3D } \\
\text { model based on 2D CAD drawings } \\
\text { of the architectural design }\end{array}$ & $\begin{array}{l}\text { Company provided the architectural } \\
\text { 3D model developed }\end{array}$ & $\begin{array}{c}\text { Researchers developed the } 3 D \\
\text { model based on } 2 D \text { CAD structural } \\
\text { design drawings }\end{array}$ \\
\hline ny & $\begin{array}{l}\text { Construction company focused in } \\
\text { the residential buildings segment }\end{array}$ & $\begin{array}{l}\text { Construction company focused in } \\
\text { the residential buildings segment }\end{array}$ & $\begin{array}{l}\text { Company de } \\
\text { solution of prefa }\end{array}$ \\
\hline Pro & $\begin{array}{c}\text { Residential condominium } \\
\text { consisting of } 99 \text { houses with } 5 \\
\text { different layouts located in Porto } \\
\text { Alegre, Brazil }\end{array}$ & $\begin{array}{c}\text { Residential condominium } \\
\text { consisting of } 5 \text {-storey towers with } \\
30 \text { apartments each located in } \\
\text { Porto Alegre, Brazil }\end{array}$ & $\begin{array}{c}\text { University campus located in Porto } \\
\text { Alegre, Brazil }\end{array}$ \\
\hline \multirow{5}{*}{$\begin{array}{l}\text { Source } \\
\text { of } \\
\text { evidence }\end{array}$} & \multicolumn{3}{|c|}{ Document analysis (including 2D designs, 3D models, and planning and control data) } \\
\hline & \multirow{2}{*}{\multicolumn{3}{|c|}{\begin{tabular}{ccc}
\multicolumn{3}{c}{ Interviews carried out with project stakeholders } \\
$\begin{array}{c}\text { 9 unstructured interviews } \\
\text { carried out with external }\end{array}$ & project manager, project planning & 6 unstructured interviews \\
consultants to discuss the & responsible and the architecture & prefabrication company and \\
plans, the BIM model needs, its & firm which developed the 3D & Company C \\
development and 4D simulation & model to identify if it would attend & \\
& 4D simulation & \\
\end{tabular}}} \\
\hline & & & \\
\hline & Site visits & Meetings with site manager wit & ith the support of 4D simulation \\
\hline & $\begin{array}{l}7 \text { site visits to compare } \\
\text { model to the constructi }\end{array}$ & $\begin{array}{l}5 \text { meetings to discuss the } \\
\text { master plan using } 4 \mathrm{D} \text { simulation }\end{array}$ & $\begin{array}{c}26 \text { meetings to dis } \\
\text { plans using } 4 \mathrm{D}\end{array}$ \\
\hline
\end{tabular}

Figure 1: Description of the empirical studies

In each empirical study, researchers attempted to identify a diversity of inputs that should be considered while developing or adapting BIM models to use for supporting 
production planning and control, i.e. inputs stemmed from projects characteristics, software and planning methods.

\section{RESULTS}

\section{EMPIRICAL STUDY 1}

In the empirical study carried out in Company A, the demands from the stakeholders involved in production planning and control (project manager, quality managers, subcontractors and external consultants) were established regarding which information should be modelled. The intended use of the BIM model was to perform 4D simulations of the construction integrated to the line of balance planning method, visualize construction sequences, verify whether scheduling was correctly done, as well as report and promote abetter understanding of the plan. It was defined which elements had to be more detailed (with higher $\mathrm{LOD}^{4}$ ) and which of them had to have more rigour while modelling to meet those needs. Therefore, the model elements were built up at LOD 200300 .

Before modelling the whole project, only one of the five house typologies was modelled and imported to Vico Office to see how effective the software communicate and share data, and which information was relevant to be modelled. The modelling process of the project was cyclical, and the BIM model was validated by the project manager and external consultants during visits carried out to the construction site.

The BIM model (Figure ) was formed by11 independent models (five of these refer to five different house typologies, and the other six refer to infrastructure and communal areas of the project). As these house types were repeated throughout the project, each of them was modelled as a '.mod' file. A module can be replicated in all corresponding locations and if any modification had to be done into the original house type file, it would reflect in all replications.

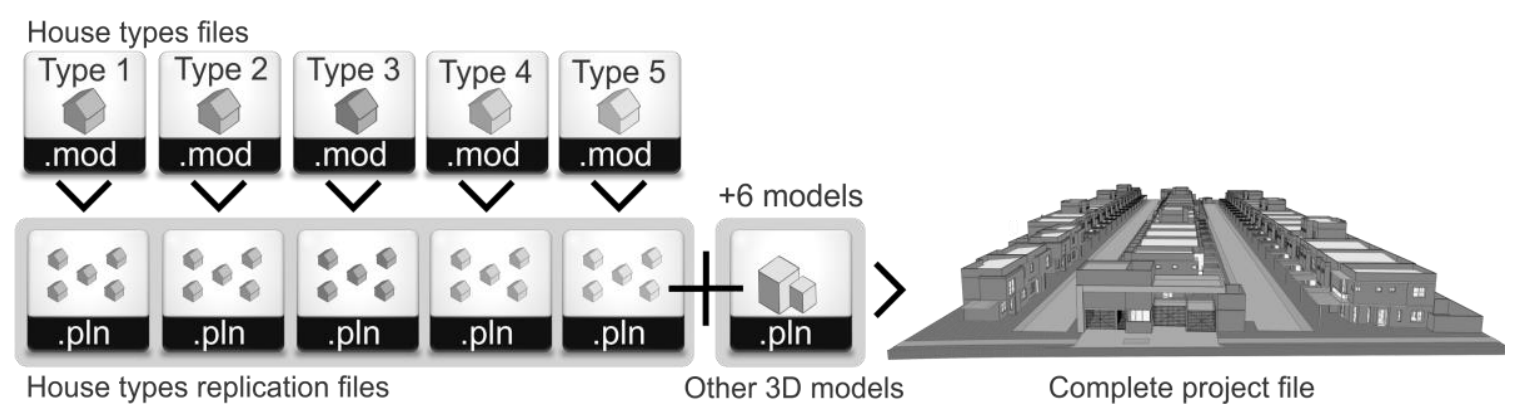

Figure 2: BIM model of the whole project and its files

The 4D software adopted in this empirical study for enabled categorizing 3D model elements according to the information inserted while modelling (e.g. material, layer). This reduced the time spent organizing elements to link them to tasks and fit the schedule.

4 Level of Development is the degree to which the elements geometry and attached information has been thought through(BIMForum 2015). 
Moreover, the 4D software splits elements geometry according to the defined locations without interfering in the BIM model, eliminating the need to decompose elements while modelling to link them to the schedule and enable performing different 4D simulations. Furthermore, using different location systems (a way to create different location breakdown structures for the same model), allowed elements to be decomposed differently depending on tasks needs.

\section{EMPIRICAL STUDY 2}

In this empirical study, Company B defined that the main usages of the model would be: (i) project documentation; (ii)early detection of project problems using the BIM model; (iii) help planners to understand the whole project; (iv) help cost estimators to perform quantities take-off.

The analysis of the BIM model enabled researchers to identify that all basic architectural elements necessary to simulate the master schedule were modelled. These elements were built up at LOD 200-300, and the BIM model was composed of four different files, merged in another one created for this purpose. In this file, the same tower was replicated five times, by using the '.mod' file (Figure 1).

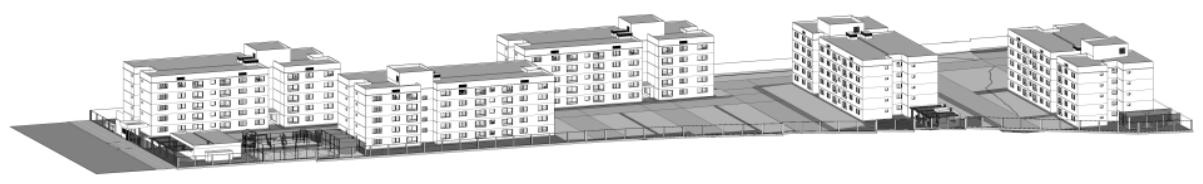

Figure 1: BIM model

The 3D BIM model was not initially developed with the aim of supporting production planning and control. However, 4D simulations were performed to find a suitable solution for the long-term plan so that the phased delivery schedule of the apartment towers was feasible. In order to achieve that, it was necessary to synchronize the cycle time of different crews, changed work sequences, perform buffer analysis, and analyse resource utilization using the $4 \mathrm{D}$ model. To be able to perform a more precise $4 \mathrm{D}$ simulation, some adaptations were necessary, such as: (i) the walls were modelled as composite elements and the 4D software recognize those grouped layers as a single layer instead. In order to link different layers of the wall to different schedule tasks, it was necessary to model a combination of basic walls representing these different layers; (ii) The existing furniture in the model was not useful for 4D simulation and ended up being deleted from the BIM model; (iii) elements were wrongly assigned to certain typologies of elements, and could cause confusion while grouping and categorizing elements to link to the schedule (e.g. knobs modelled as doors, chimneys modelled as columns).

\section{EMPIRICAL STUDY 3}

In this empirical study, the 4D model was used to support decision-making with focus on planning and control of prefabricated concrete structure assembly tasks. The 4D model potential user was the site manager and it was used in planning meetings to support collaborative processes, in which different stakeholders took part (project coordinators 
and engineers from other companies, foreman, subcontractors and workers). The relevant information was related to concrete components' identification data, location and orientation according to defined axes, as well as to the construction site (e.g. pathways, inventory areas, and equipment).

Families of prefabricated components were created, and a specific identification code for each of them was inserted into 3D elements according to company standards (Figure ). These codes were an important identification throughout all company controls (manufacturing, expedition and assembly).

The project was divided into three assembly sectors that enabled segmentation of the execution deadline and the control of milestones, and consequently, the BIM model was segmented into three modelling batches. The prefabricated elements were modelled at LOD 300 and construction site elements were modelled at LOD 200.Figure shows the steps taken in this study and the time spent on each of them. Based on that, it is worth noting the reduction of time spent in sector 2 and 3, due to the use of families of components.

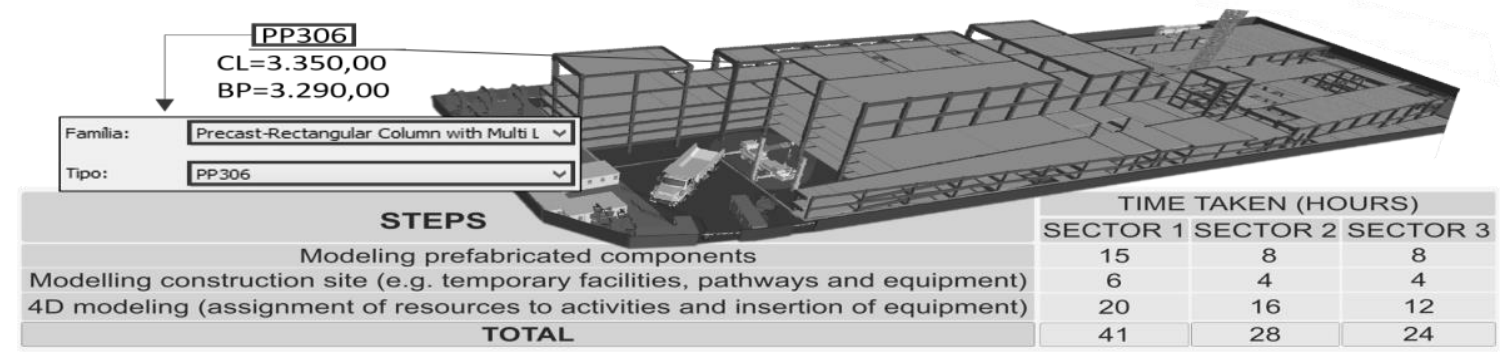

Figure 4: Component code in the BIM model and the time spent in each modelling step

\section{GUIDELINES FOR 3D MODELLING TO SUPPORT PRODUCTION PLANNING AND CONTROL}

Based on the analysis of the empirical studies, it was possible to identify the origins of $3 \mathrm{D}$ modelling demands in order to address required information to support production planning and control (Figure 2). In this paper, these were named inputs for 3D modelling. The decisions that impact these inputs (Figure 5)were divided into general and specific, as well as 3D modelling inputs were divided into categories.

The inputs from the 4D software are concerned with implications and limitations of the software used, which may be related to the method adopted for scheduling work. It is important to identify that if the 4D software enables element geometry splitting (divide elements into parts) and how this is done. Also, it is important to determine if information inserted into the BIM model can facilitate elements categorization (renaming, grouping and ungrouping) to assign them to schedule tasks (e.g. use two different layers to divide a single element typology that must be assigned to two different tasks). Furthermore, information inserted could be standardized (e.g. elements name, layers and codes) to facilitate schedulers work. Additionally, it is important to define how information is 
going to be used and which are the 4D model outputs (e.g. videos, snapshots, BIM model manipulation for dynamic visualization).
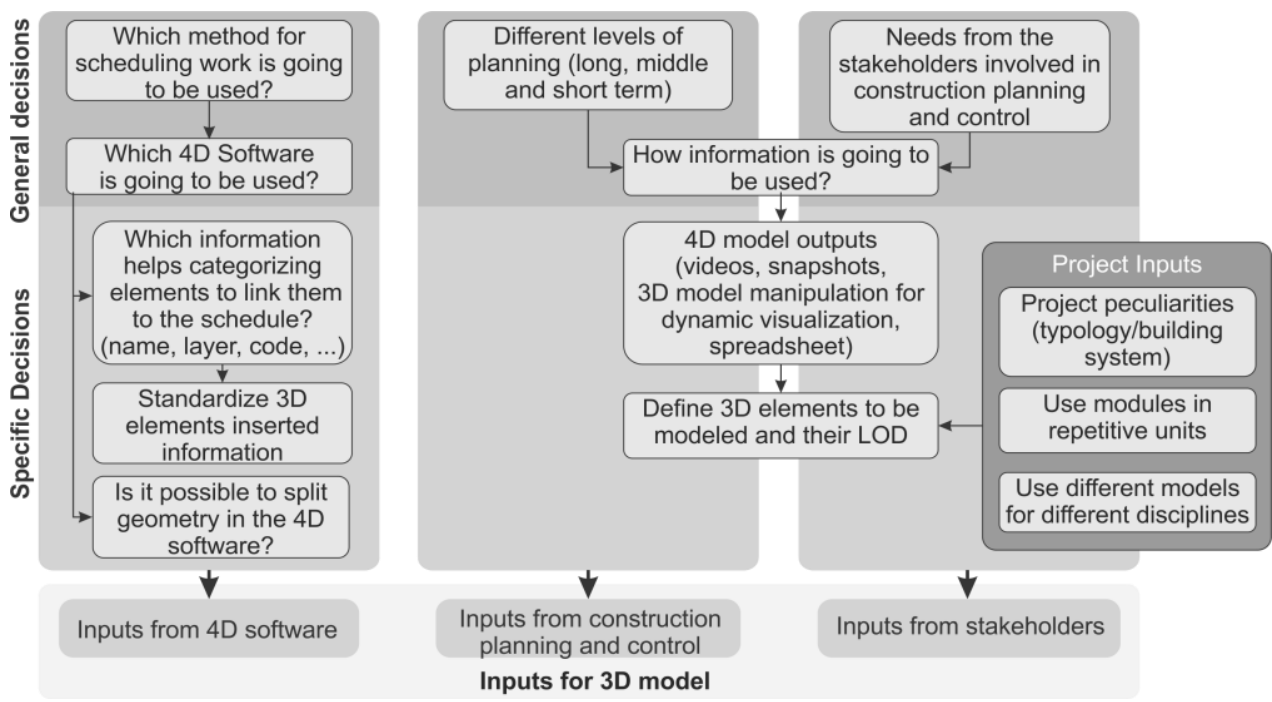

Figure 2: BIM model development inputs origins

The inputs from production planning and control are related to how detailed the task is, which is a consequence of the planning system decisions (e.g. hierarchical planning system). So, it is important to define 3D elements' LOD according to schedule needs (e.g. wall as a singular layer or composed of bricks, mortar, plaster and painting). Moreover, it is important to identify inputs from stakeholders involved in production planning and control (e.g. quality managers, subcontractors, engineers, project manager).Authors could not find a generic solution to define which elements have to be modelled and their corresponding LODs to any case. To help that, the modelled elements along with the LODs adopted were presented in each empirical study.

The inputs from projects are related to project peculiarities, for example, project typology (horizontal or vertical building) and building system (prefabricated components or conventional construction), intrinsic characteristics from repetitive projects (e.g. repetition of floors, houses, apartments or even parts of it). If the project has repetitive characteristics and these are addressed, it can reduce rework while modifying only the original repetitive module. Furthermore, individualizing BIM models (different design disciplines) can make it easy to reinsert the model by only importing the modified information.

Based on the origins of 3D modelling inputs, researchers proposed a set of guidelines to be addressed in order to develop a BIM model to support production planning and control. Furthermore, an analysis was undertaken on how these guidelines addressed lean principles based on evidences obtained in the empirical studies content. The starting point for this analysis was the article of Sacks et al. (2010), which explores the interactions between BIM functionalities and Lean principles. Figure 3provide some evidences of these interactions, obtained from the empirical studies. The guidelines are explained in Figure 4. 


\begin{tabular}{|c|c|c|c|c|}
\hline \multirow{2}{*}{ Guidelines } & \multicolumn{3}{|c|}{ Main evidences related to the empirical cases } & \multirow{2}{*}{$\begin{array}{l}\text { Lean } \\
\text { principles }\end{array}$} \\
\hline & Case 1 & Case 2 & Case 3 & \\
\hline $\begin{array}{l}\text { Standardize } \\
\text { elements according } \\
\text { to planners use }\end{array}$ & \multicolumn{2}{|c|}{$\begin{array}{l}\text { Information was standardized to easily } \\
\text { identify and categorize elements inside } \\
\text { 4D software to link it to the schedule }\end{array}$} & \begin{tabular}{|c|} 
Information was \\
standardized so \\
components code could be \\
extracted to a production \\
sheet
\end{tabular} & Standardize \\
\hline $\begin{array}{l}\text { Define } 3 D \text { elements } \\
\text { to be modelled and } \\
\text { their LOD }\end{array}$ & \multicolumn{2}{|c|}{$\begin{array}{l}\text { Use of videos and snapshots of master } \\
\text { plan's sequencing (process) }\end{array}$} & \begin{tabular}{|c|} 
Use of videos and \\
snapshots of assembly \\
sequencing (method and \\
process)
\end{tabular} & \begin{tabular}{|c|} 
Use visual \\
management to \\
visualize methods \\
or processes \\
\end{tabular} \\
\hline \multirow{2}{*}{$\begin{array}{l}\text { Identify stakeholders } \\
\text { needs related to } \\
\text { production planning } \\
\text { and control, and the } \\
\text { appropriated 4D } \\
\text { output for them }\end{array}$} & \multicolumn{3}{|c|}{$\begin{array}{l}\text { Understanding phase of DSR - understand company's context and } \\
\text { analysis of the production planning and control methods adopted by } \\
\text { the companies }\end{array}$} & $\begin{array}{l}\text { Ensure } \\
\text { comprehensive } \\
\text { requirement } \\
\text { capture }\end{array}$ \\
\hline & \multicolumn{3}{|c|}{$\begin{array}{c}\text { Stakeholders understood more easily the plans by using different 4D } \\
\text { outputs }\end{array}$} & $\begin{array}{l}\text { Increase output } \\
\quad \text { value }\end{array}$ \\
\hline $\begin{array}{l}\text { Standardize } \\
\text { elements according } \\
\text { to planners use }\end{array}$ & \multicolumn{2}{|c|}{$\begin{array}{l}\text { Elements categorization got easier to } \\
\text { perform because elements were } \\
\text { modeled with information that enabled } \\
\text { grouping and ungrouping elements }\end{array}$} & $\begin{array}{l}\text { Automatization of } \\
\text { extraction of the } \\
\text { components production } \\
\text { and assembly information }\end{array}$ & \multirow{4}{*}{$\begin{array}{l}\text { Reduce non value- } \\
\text { adding activities }\end{array}$} \\
\hline $\begin{array}{c}\text { Define 3D elements } \\
\text { to be modelled and } \\
\text { their LOD }\end{array}$ & \multicolumn{3}{|c|}{ Modelling only necessary information reduced time spent on it } & \\
\hline $\begin{array}{l}\text { Identify repetition } \\
\text { inside the project }\end{array}$ & $\begin{array}{l}\text { Simplify 3D } \\
\text { modelling by using } \\
\text { repetitive houses }\end{array}$ & \begin{tabular}{|c} 
Simplify 3D \\
modelling by using \\
repetitive \\
apartments and \\
building \\
\end{tabular} & $\begin{array}{l}\text { Simplify 3D modelling by } \\
\text { using repetitive } \\
\text { components }\end{array}$ & \\
\hline $\begin{array}{l}\text { Define the method } \\
\text { for scheduling work } \\
\text { that is going to be } \\
\text { used and then if the } \\
\text { 4D software chosen } \\
\text { enables dividing } \\
\text { elements into parts }\end{array}$ & \multicolumn{2}{|c|}{$\begin{array}{l}\text { As the 4D software enabled geometry } \\
\text { splitting, it was not necessary to do it } \\
\text { while developing the 3D model. } \\
\text { Whenever necessary it was possible to } \\
\text { split elements differently inside the 4D } \\
\text { environment. }\end{array}$} & & \\
\hline $\begin{array}{c}\text { Define 3D elements } \\
\text { to be modelled and } \\
\text { their LOD }\end{array}$ & \multicolumn{3}{|c|}{ Necessary information was available to support decision making } & Reduce variability \\
\hline \multirow{2}{*}{$\begin{array}{l}\text { Define to which level } \\
\text { of planning (long, } \\
\text { middle or short term) } \\
\text { 4D simulation will be } \\
\text { used and establish } \\
\text { 3D model LOD } \\
\text { according to it }\end{array}$} & \multirow[b]{2}{*}{$\begin{array}{c}\text { 4D model was used } \\
\text { to simulate master } \\
\text { plan }\end{array}$} & \multirow[b]{2}{*}{$\begin{array}{l}\text { 4D model was used } \\
\text { to simulate master } \\
\text { and mid-term plans }\end{array}$} & \multirow[b]{2}{*}{$\begin{array}{l}\text { 4D model was used to } \\
\text { simulate master, mid and } \\
\text { short term plans with }\end{array}$} & \\
\hline & & & & $\begin{array}{c}\text { Select an } \\
\text { appropriate } \\
\text { production control } \\
\text { approach - Level } \\
\text { the production }\end{array}$ \\
\hline $\begin{array}{l}\text { Define if operations } \\
\text { are going to be } \\
\text { simulated and if so } \\
\text { model inventory } \\
\text { areas, equipment, } \\
\text { temporary facilities } \\
\text { and accesses } \\
\end{array}$ & - & - & \begin{tabular}{|c|} 
4D simulation of planning \\
and control logistics \\
operations such as loading \\
and unloading \\
components, equipment \\
movement and site \\
inventories control
\end{tabular} & Reduce cycle time \\
\hline
\end{tabular}

Figure 3: Lean and BIM interactions based on evidences from the empirical studies 


\begin{tabular}{|c|c|}
\hline $\begin{array}{l}\text { Standardize elements according to } \\
\text { planners use }\end{array}$ & $\begin{array}{l}\text { The standardization can facilitate and reduce planners working time by } \\
\text { addressing their specific uses, and also reduce planner non-value } \\
\text { adding activities, by reducing time to perform planning related activities. }\end{array}$ \\
\hline $\begin{array}{l}\text { Identify stakeholder needs related to } \\
\text { production planning and control and } \\
\text { the appropriated 4D output for them }\end{array}$ & $\begin{array}{l}\text { Addressing relevant information by enhancing requirements capture can } \\
\text { increase the output value to stakeholders as they understand the } \\
\text { processes and methods more easily. }\end{array}$ \\
\hline $\begin{array}{c}\text { Define to which level of planning } \\
\text { (long, middle or short term) the 4D } \\
\text { simulation will be used and } \\
\text { establish elements LOD according } \\
\text { to it }\end{array}$ & $\begin{array}{l}\text { These definitions can reduce production variability by visualizing and } \\
\text { understanding workflows, which can be simplified by a visual output. } \\
\text { Moreover, it can improve planning by forcing planners to think about } \\
\text { production levelling, which can be supported with enough information } \\
\text { from 4D models. }\end{array}$ \\
\hline $\begin{array}{l}\text { Define if operations are going to be } \\
\text { simulated and if so model inventory } \\
\text { areas, equipment, temporary } \\
\text { facilities and accesses }\end{array}$ & $\begin{array}{l}\text { Modelling important elements to operations enable logistics simulation } \\
\text { and consequently helps reducing cycle time by minimizing non-value } \\
\text { adding activities related to these operations. }\end{array}$ \\
\hline $\begin{array}{l}\text { Define 3D elements to be modelled } \\
\text { and their LOD }\end{array}$ & $\begin{array}{l}\text { These definitions allow planners to visualize construction processes and } \\
\text { methods with the level of detail needed. Moreover, it provides enough } \\
\text { information for planners to detect and solve problems using 4D } \\
\text { information before these problems interfere in the production planning. }\end{array}$ \\
\hline Identify repetition inside the project & $\begin{array}{l}\text { The identification of identical repetitive modules enables modeller to } \\
\text { reuse model's information. }\end{array}$ \\
\hline $\begin{array}{c}\text { Define the method for scheduling } \\
\text { work that is going to be used, then } \\
\text { chose the 4D software and identify if } \\
\text { it enables splitting elements } \\
\text { geometry }\end{array}$ & $\begin{array}{l}\text { Identifying if the 4D software allow splitting elements geometry eliminate } \\
\text { modellers need to split elements while developing the 3D model. By } \\
\text { contrast, if the software does not do it, output value can be increased if } \\
\text { modellers split them into the 3D software, as it enables more } \\
\text { construction simulation options. }\end{array}$ \\
\hline
\end{tabular}

Figure 4: Guidelines do develop BIM models focused on production planning and control

\section{CONCLUSIONS}

The basis for the discussion and establishment of the set of guidelines emerged from the attempt to identify the inputs to build up BIM models that were used to support planning and control processes. Some interactions between Lean principles and BIM functionalities that were identified in the empirical studies support the idea that the adoption of these guidelines to develop BIM models can enhance Lean outcomes. As a contribution, the authors have identified an increase of collaboration, while people tried to express their needs referring to the model. The understanding and engagement in the project by all parties involved increased the process transparency since it made clearer to people which information was relevant to the model and why it was not necessarily highly detailed. Moreover, results from the empirical studies showed that the application of these guidelines can help eliminating non-value adding activities, increase output values, and reduce the time spent in 3D modelling. During the analysis and reflection phase, it was possible to identify that to support production planning and control, the BIM model must be modelled with relevant and sufficient information according to its particular use, project peculiarities and stakeholders needs.

\section{ACKNOWLEDGEMENTS}

We would like to thank $\mathrm{CNPq}$ for the financial support for this research project and the companies involved in this research study. 


\section{REFERENCES}

Ballard, G., and Howell, G. (1998). "Shielding Production: Essencialstep in production control." Journal of Civil Engineering and Management, 124(1), 11-17.

Boton, C., Kubicki, S., and Halin, G. (2015). "The Challenge of Level of Development in 4D/BIM Simulation Across AEC Project Lifecyle. A Case Study." Procedia Engineering, 123, 59-67.

Crotty, R. (2012). The Impact of Building Information Modelling: Transforming Construction. SPON Press.

Dave, B., Boddy, S., and Koskela, L. (2011). "Visilean: designing a production management system with lean and BIM." 19th Ann. Conf. of the IGLC, 514-524.

Eastman, C., Teicholz, P., Sacks, R., and Liston, K. (2011). BIM Handbook - A Guide to Building Information Modeling for Owners, Managers, Designers, Engineers, and Contractors. John Wilet\& Sons, Inc., New Jersey.

Fosse, R., Ballard, G., and Fischer, M. (2017). "Virtual Design and Construction: Aligning BIM and Lean in Practice." Proc. 25th Ann. Conf. of the IGLC, 499-506.

Gledson, B. J., and Greenwood, D. (2014). "The implementation and use of 4D BIM and virtual construction." Proc. 30th Ann. ARCOM Conference, 673-682.

Gledson, B. J., and Greenwood, D. (2017). "The adoption of 4D BIM in the UK construction industry: an innovation diffusion approach." Engineering, Construction and Architectural Management, 24(6), 950-967.

Heesom, D., and Mahdjoubi, L. (2002). "A dynamic 4D simulation system for construction space planning." Proc. of the Third International Conference on Decision Making in Urban and Civil Engineering, 1-6.

Holmström, J., Ketokivi, M., and Hameri, A.-P. (2009). "Bridging Practice and Theory: A Design Science Approach.” Decision Science, 40(1), 65-87.

Kasanen, E., Lukka, K., and Siitonen, A. (1993). "The Constructive Approach in Management Accounting Research." Journal of Management Accounting Research, 5, 243-264.

Kim, C., Kim, C., and Son, H. (2013). "Automated construction progress measurement using a 4D building information model and 3D data." Automation in Construction, Elsevier B.V., 31, 75-82.

Li, H., Chan, N., Huang, T., Guo, H. L., Lu, W., and Skitmore, M. (2009). "Optimizing construction planning schedules by virtual prototyping enabled resource analysis." Automation in Construction, Elsevier B.V., 18(7), 912-918.

Li, Y., Stephens, J., and Ryba, A. (2014). "Four-dimensional modelling on Tottenham Court Road station, London, UK.” Proc.Institution of Civil Engineers, 33-40.

Sacks, R., Koskela, L., Dave, B. A., and Owen, R. (2010). "Interaction of Lean and Building Information Modeling in Construction." Journal of Construction Engineering and Management, 136(9), 968-980.

Sulankivi, K., Kahkonen, K., Mäkelä, T., and Kiviniemi, M. (2010). "4D-BIM for construction safety planning." Proceedings of W099-Special..., 117-128.

Zhang, J., and Li, D. (2010). "Research on 4D Virtual Construction and Dynamic Management System Based on BIM." Nottingham University Press. 